\title{
Vesnarinone, a differentiation inducing drug, directly activates p2 I wafl gene promoter via SpI sites in a human salivary gland cancer cell line
}

\author{
F Omotehara ${ }^{1,5}$, H Kawamata*,1,5, D Uchida ${ }^{2}$, S Hino ${ }^{3}$, K Nakashiro ${ }^{4}$ and T Fujimori' \\ 'Department of Surgical and Molecular Pathology, Dokkyo University School of Medicine, 880 Kitakobayashi, Mibu, Shimo-Tsuga, Tochigi, 32 I-0293, Japan; \\ ${ }^{2}$ Second Department of Oral and Maxillofacial Surgery, Tokushima University School of Dentistry, 3-18-15 Kuramoto, Tokushima, 770-8504, Japan; \\ ${ }^{3}$ Division of Genetic Information, Institute for Genome Research, University of Tokushima, 3-I 8-15 Kuramoto, Tokushima, 770-8503, Japan; \\ ${ }^{4}$ Department of Oral and Maxillofacial Surgery, Ehime University School of Medicine, 454 Shitsukawa, Shigenobu, Onsen, Ehime, 79I-0295, Japan
}

We previously demonstrated that a differentiation inducing drug, vesnarinone induced the growth arrest and $p 2$ I $^{\text {wafl }}$ gene expression in a human salivary gland cancer cell line, TYS. In the present study, we investigated the mechanism of the induction of $p 2 l^{\text {wafl }}$ gene by vesnarinone in TYS cells. We constructed several reporter plasmids containing the $p 2 l^{\text {wafl }}$ promoter, and attempted to identify vesnarinone-responsive elements in the $p 2 l^{\text {wafl }}$ promoter. By the luciferase reporter assay, we identified the minimal vesnarinone-responsive element in the $p 2 l^{\text {wafl }}$ promoter at $-\mid 24$ to $-6 \mid$ relative to the transcription start site. Moreover, we demonstrated by electrophoretic mobility shift assay that SpI and Sp3 transcription factors bound to the vesnarinone-responsive element. Furthermore, we found that vesnarinone induced the histone hyperacetylation in TYS cells. These results suggest that vesnarinone directly activates $p 2 I^{\text {wafl }}$ promoter via the activation of Spl and Sp3 transcription factors and the histone hyperacetylation in TYS cells.

British Journal of Cancer (2002) 87, 1042 - 1046. doi:I0.1038/sj.bjc.6600592 www.bjcancer.com

(C) 2002 Cancer Research UK

Keywords: vesnarinone; 2 I $^{\text {wafl }}$; transcription; Spl; histone-acetylation; salivary gland cancer

We have previously demonstrated that a differentiation inducing drug, vesnarinone inhibits the growth of a human salivary gland cancer cell line, TYS, and induces the expression of $\mathrm{p} 21^{\text {waf1 }}$, a potent inhibitor of cyclin dependent kinase (Sato et al, 1997a; Kawamata et al, 1998). Vesnarinone is currently used as a chemotherapeutic agent for head and neck cancer combined with radiation in several countries, such as Japan (Sato et al, 1997b,c), the United States and India. $p 21^{\text {wafl }}$ is a gene functioning as a cell cycle blocker, and its expression is usually regulated at transcriptional level. p $21^{\text {waf1 }}$ is known to inhibit cyclin dependent kinase activity in p53-mediated cell cycle arrest induced by DNA damage (El-Deiry et al, 1993). Further studies have indicated that $p 21^{\text {wafl }}$ is also regulated by other transcription factors during cell differentiation and growth arrest (Dulic et al, 1994; Jiang et al, 1994). p21 wafi promoter contains not only p53-binding sites but also several transcription factor responsive elements (Datto et al, 1995; Nakano et al, 1997). One of the responsive elements is for a transcription factor, Sp1. Sp1 responsive elements are located on the upstream of TATA box of $p 21^{\text {wafi }}$ promoter. It is reported that several extracellular stimuli including butyrate (Nakano et al, 1997), transforming growth factor- $\beta$ (Datto et al, 1995), phorbol esters (Biggs et al, 1996), okadaic acid (Biggs et al, 1996) and retinoic acid (Liu et al, 1996) activate the transcription of $p 21^{\text {wafl }}$ gene through the Sp1 responsive elements.

*Correspondence: H Kawamata; E-mail: h-kawama@dokkyomed.ac.jp ${ }^{5} \mathrm{~F}$ Omotehara and $\mathrm{H}$ Kawamata contributed equally to this paper.

Received 21 June 2002; revised 6 August 2002; accepted I5 August 2002
Because TYS cells are reported to have a mutated $p 53$ gene (Sato et al, 1997a), the expression of $p 21^{\text {wafl }}$ gene and the growth arrest induced by vesnarinone may be conducted by the $\mathrm{p} 53$-independent pathway in TYS cells. In order to use vesnarinone more effectively on the patients with several malignancies, including head and neck cancer, the molecular mechanisms of the growth inhibitory effect of vesnarinone should be studied. In this experiment, we attempted to identify the vesnarinone-responsive elements in the $p 21^{\text {wafl }}$ promoter, and clarify the molecular mechanisms of transcriptional activation of $p 21^{\text {wafl }}$ gene by treatment with vesnarinone in a human salivary gland cancer cell line, TYS.

\section{MATERIALS AND METHODS}

\section{Cell culture and reagents}

TYS cells (Yanagawa et al, 1986) were grown in Dulbecco's modified Eagle medium (DMEM; Life Technologies, Inc., Gaithersburg, MD, USA) supplemented with $10 \%$ foetal calf serum (FCS; BioWhittaker, Walkersville, MD), $100 \mu \mathrm{g} \mathrm{ml}^{-1}$ streptomycin, $100 \mathrm{U} \mathrm{ml}^{-1}$ penicillin (Life Technologies, Inc.), and $0.25 \mu \mathrm{g} \mathrm{ml}$ amphotericin B (Life Technologies, Inc.) in a humidified atmosphere of $95 \%$ air and $5 \% \mathrm{CO}_{2}$ at $37^{\circ} \mathrm{C}$. Vesnarinone (Otsuka Pharmaceutical Company, Tokyo, Japan) was dissolved in dimethyl sulphoxide (DMSO; Sigma, St. Louis, MO, USA) at a concentration of $10 \mathrm{mg} \mathrm{ml}^{-1}$ as the first stock solution, and the first stock solution was diluted with the complete culture medium described above. Trichostatin A (TSA; Wako, Osaka, Japan) was dissolved in ethanol at a concentration of $1 \mathrm{mg} \mathrm{ml}^{-1}$, and diluted with the complete culture medium at $10 \mu \mathrm{g} \mathrm{ml}^{-1}$. 


\section{Plasmid preparation}

The human wild-type $p 21^{\text {waf } 1}$ promoter luciferase fusion plasmid, WWP-Luc (El-Deiry et al, 1993), was a kind gift from Dr B Vogelstein (The Johns Hopkins Oncology Center). The 2.4-kilobase pair genomic fragment was subcloned into HindIII (Takara Biomedicals, Kusatsu, Japan) site of the luciferase reporter vector, $p G L 3$ Basic (Promega, Madison, WI, USA) to generate pGL3-WWP (Kawamata et al, 1999) (Figure 1). pGL3-WWP was digested with PstI (Takara Biomedicals) and BglII (Takara Biomedicals), and re-ligated to generate $p G L 3-W W P-0.2$ (Figure 1). $p W P 124$ and pWPdel-SmaI (Nakano et al, 1997) (Figure 1) were kind gifts from Dr Toshiyuki Sakai (Kyoto Prefectural University of Medicine).

\section{Transient transfection and luciferase assay}

TYS cells $\left(5 \times 10^{5}\right.$ cells dish $\left.{ }^{-1}\right)$ were seeded in $35 \mathrm{~mm}$ culture dish (Falcon; Becton Dickinson Labware, Lincoln Park, NJ, USA) in DMEM supplemented with $10 \%$ FCS. Twenty-four hours later, the cells were transfected with $5 \mu \mathrm{g}$ of reporter plasmid DNA by using Superfect reagent (QIAGEN, Hilden, Germany). Fifteen hours after transfection, vesnarinone $\left(50 \mu \mathrm{g} \mathrm{ml}^{-1}\right)$ was added, and $20 \mathrm{~h}$ later, cell lysates were collected. Luciferase activities were measured by Promega luciferase assay Kit (Promega). The luciferase activities were normalised by the amount of protein. Each experiment was repeated at least three times.

\section{Electrophoretic mobility-shift assay}

TYS cells $\left(1.5 \times 10^{6}\right.$ cells dish $\left.^{-1}\right)$ were seeded in $100 \mathrm{~mm}$ culture dish (Falcon) in DMEM supplemented with 10\% FCS. Twenty-four hours later, cells were treated with vesnarinone $\left(50 \mu \mathrm{g} \mathrm{ml}^{-1}\right)$ for 15, 30 and $45 \mathrm{~min}$. Cell lysates were prepared according to the method described by Chin et al (1996). In brief, cells were lysed with $50 \mathrm{~mm}$ HEPES-KOH ( $\mathrm{pH} 7.9$ ) buffer containing $400 \mathrm{~mm}$ $\mathrm{NaCl}, 0.2 \%$ NP-40, $10 \%$ glycerol, $0.1 \mathrm{~mm}$ EDTA, $1 \mathrm{~mm}$ dithiothreitol (DTT), $1 \mathrm{mM}$ sodium orthovanadate, $0.5 \mathrm{~mm}$ phenylmethanesulphonyl fluoride (PMSF), $1 \mu \mathrm{g} \mathrm{ml}^{-1}$ of aprotinin, $1 \mu \mathrm{g} \mathrm{ml}^{-1}$ of leupeptin, and $1 \mu \mathrm{g} \mathrm{ml}^{-1}$ of pepstatin $\mathrm{A}$. The protein concentrations of samples were determined with a BioRad protein assay kit (Bio-Rad, Hercules, CA, USA). Double stranded oligonucleotides, (Sp1-A: 5'-GAG GGC GGT CCC GGG CGG CG-3', and Sp1-B: $5^{\prime}$-GAG GCG GGC CCG GGC GGG GCG GTT G-3') (Figure 2) were labelled with $\left[\gamma_{-}{ }^{32}\right.$ p]ATP (Amersham Pharmacia Biotech., Uppsala, Sweden) by T4 polynucleotide kinase (Promega), and purified by a spin column system (Amersham Pharmacia Biotech.). Sp1-A contains two Spl sites, and $S p 1-B$ contains three Sp1 sites (Figure 2). The binding reaction mixtures consisted of $12 \mu \mathrm{g}$ of cell lysates and $1 \mu \mathrm{l}$ of the radiolabelled probe (approximately $5 \times 10^{4}$ c.p.m.) in a binding buffer of $10 \mathrm{mM}$ HEPES-KOH (pH 7.9), $0.1 \mathrm{mM}$ EDTA, $0.01 \%$ NP-40, $100 \mu \mathrm{g} \mathrm{ml}^{-1}$ of poly (dI-dC) (Amersham Pharmacia Biotech.), and $5 \%$ glycerol. The reaction was allowed to proceed for $20 \mathrm{~min}$ at room temperature before loading on $6 \%$ polyacrylamide gel at a low-ionic-strength buffer $(0.5 \times \mathrm{TBE})$. The gels were run at $100 \mathrm{~V}$ on ice for approximately $1 \mathrm{~h}$ and dried. The dried gels were exposed to X-ray film. For supershift experiments, anti-Sp1 and/or anti-Sp3 antibody (Santa Cruz Biotechnology, Santa Cruz, CA, USA) was added to the reaction mixture, and the mixture was incubated for $20 \mathrm{~min}$ at room temperature before addition of the radiolabelled oligonucleotide.

\section{Histone acetylation in TYS cells by vesnarinone treatment}

TYS cells were seeded in $100 \mathrm{~mm}$ culture dishes. Twenty-four hours later, vesnarinone $\left(50 \mu \mathrm{g} \mathrm{ml}^{-1}\right)$ or TSA $\left(10 \mu \mathrm{g} \mathrm{ml}^{-1}\right)$ was added to the medium. Sixteen hours later, the cells were collected and the nuclear extracts were prepared as follows; cells were suspended in $400 \mu \mathrm{l}$ of hypotonic buffer (20 mM HEPES-KOH (pH 7.9) containing $1 \mathrm{mM}$ EDTA, $1 \mathrm{~mm}$ DTT, $20 \mathrm{~mm} \mathrm{NaF}$, $1 \mathrm{~mm}$ sodium orthovanadate, $0.5 \mathrm{mM}$ PMSF, $0.2 \%$ NP-40, $1 \mu \mathrm{g} \mathrm{ml}^{-1}$ leupeptin, 10 units $\mathrm{ml}^{-1}$ aprotinin, and $1 \mu \mathrm{g} \mathrm{ml}^{-1}$ pepstatin A). Samples were centrifuged at 15000 r.p.m. and the pellets were resuspended in $200 \mu \mathrm{l}$ of hypertonic buffer $(20 \mathrm{mM}$ HEPES-KOH (pH 7.9) containing $1 \mathrm{mM}$ EDTA, $1 \mathrm{mM}$ DTT, $20 \mathrm{mM} \mathrm{NaF}, 1 \mathrm{~mm}$ sodium orthovanadate, $0.5 \mathrm{~mm}$ PMSF, $0.2 \%$ NP-40, $420 \mathrm{~mm} \mathrm{NaCl}, 20 \%$ glycerol, $1 \mu \mathrm{g} \mathrm{m}^{-1}$ leupeptin, 10 units $\mathrm{ml}^{-1}$ aprotinin, and $1 \mu \mathrm{g} \mathrm{ml}^{-1}$ pepstatin A). Samples were incubated on ice for $20 \mathrm{~min}$ and were centrifuged at 15000 r.p.m. for $15 \mathrm{~min}$. The supernatants were used as nuclear extracts. The protein concentrations of samples were determined with a Bio-Rad protein assay. Samples were electrophoresed on SDS-polyacrylamide gel. Proteins from gels were transferred to nitrocellulose (Bio-Rad) and were detected with an anti-acetylated Histone H3 antibody (Upstate Biotechnology, Lake Placid, NY, USA) and an Amersham ECL kit (Amersham Pharmacia Biotech.).

\section{RESULTS}

\section{Effect of vesnarinone on the activation of $p 21^{\text {wafl }}$ promoter}

Several reporter plasmids (Figure 1) were transiently transfected in TYS cells, and luciferase activity was examined. Vesnarinone apparently enhanced the luciferase activity from the $p G L 3-W W P$ reporter plasmid in TYS cells when compared with untreated control or DMSO treatment (Figure 3). Vesnarinone also enhanced the luciferase activity from the $p G L 3-W W P-0.2$ plasmid, which contained a $215 \mathrm{bp}$ promoter fragment lacking two p53 binding sites (Figure 3). Surprisingly, vesnarinone also enhanced the luciferase activity from the $p W P 124$ containing only a $124 \mathrm{bp}$ promoter fragment. However, vesnarinone did not activate a $60 \mathrm{bp}$ promoter fragment of $p 21^{\text {waf1 }}$ in $p W P d e l-S m a I$ reporter plasmid (Figure 3 ).

\section{Electrophoretic mobility-shift assay}

According to the results from the luciferase assay, the vesnarinoneresponsive element exists within $77 \mathrm{bp}$ region relative to the TATA element. This $77 \mathrm{bp}$ region harbours four independent and two overlapping nearly consensus binding sites for transcription factor Sp1. They are tentatively termed $S p 1-1, S p 1-2, S p 1-3, S p 1-4, S p 1-5$ and $S p 1-6$ from the upstream (Figure 2). To determine if $S p 1$ or other proteins can interact with the vesnarinone-responsive element, electrophoretic mobility-shift assay was performed using the oligonucleotides containing the Sp1-binding sites. The $S p 1-A$ contains Sp1-1 and Sp1-2 sites, and the Sp1-B contains Sp1-4, $S p 1-5$ and $S p 1-6$ sites (Figure 2). After treatment with vesnarinone for $30 \mathrm{~min}$, we detected the shifted band when using the $S p 1-A$ as a probe (Figure 4A). However, when we used the $S p 1-B$, we could not detect any shifted bands after vesnarinone treatment (Figure 4A). As shown in Figure 4B, the mobility shift was detectable at $30 \mathrm{~min}$ after treatment with $50 \mu \mathrm{g} \mathrm{ml}^{-1}$ vesnarinone, and the intensity of the shifted band increased at $45 \mathrm{~min}$ after treatment. Moreover, this band completely disappeared by adding excess unlabelled Sp1-A oligonucleotide (data not shown).

\section{Supershift assay}

To elucidate whether the retarded bands represent the binding of Sp1 or Sp3, supershift assay was performed by the nuclear extracts pre-incubated with anti-Sp1 or anti-Sp3 antibody (Figure $4 C)$. In the presence of anti-Sp1 or anti-Sp3 antibody, the intensity of the shifted band was markedly reduced. The shifted band completely disappeared in the presence of anti-Sp1 and anti-Sp3 antibody together. When pre-immune rabbit-IgG was added as a 


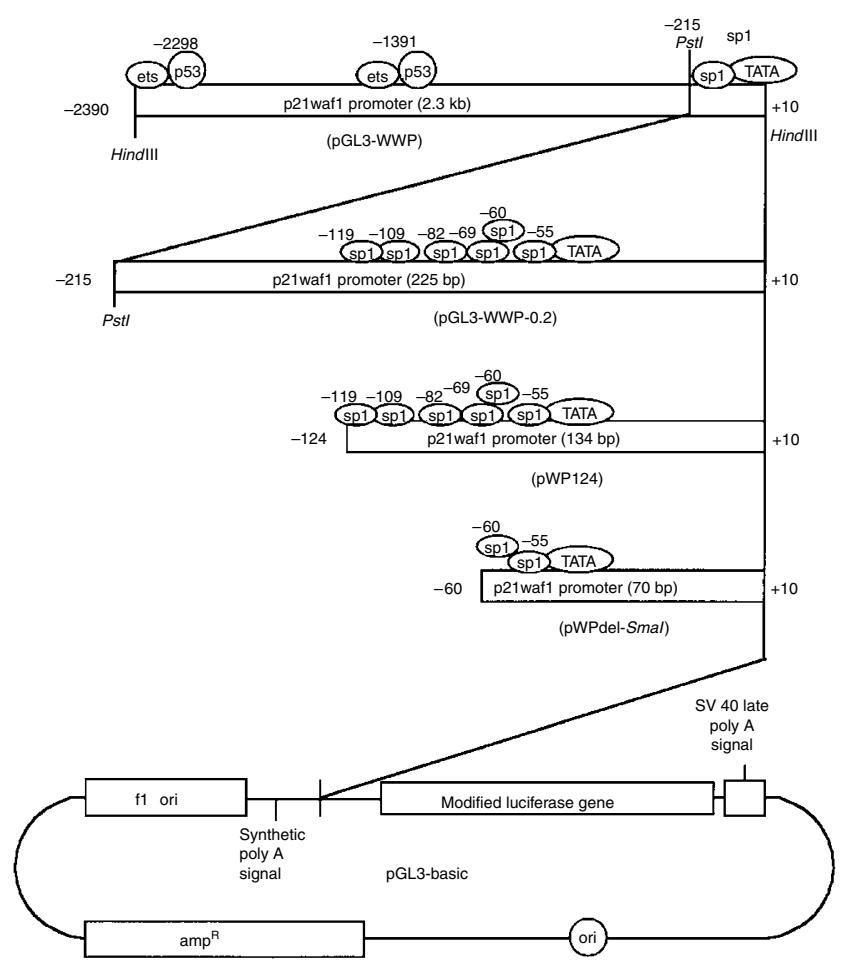

Figure I Plasmid construction. pGL3-WWP is a reporter construct containing $2.3 \mathrm{~kb} p 2 I^{\text {wafl }}$ promoter sequence. pGL3-WWP-0.2, pWPI 24 and pWPdel-Smal are 5 -deletion constructs of the $p 2 I^{\text {wafl }}$ promoter. $p G L 3$ WWP-0.2 contains 225 bp of $p 21^{\text {wafl }}$ promoter sequence. pWPI24 contains $134 \mathrm{bp}$ and $p$ WPdel-Smal contains $70 \mathrm{bp}$ of $p 2 I^{\text {wafl }}$ promoter sequence.



Figure 2 Human $p 2 l^{\text {wafl }}$ promoter sequence located between $-215 \mathrm{bp}$ and $+19 \mathrm{bp}$. The transcription start site is indicated by the number 0 on the sequence. Sp I binding sites tentatively termed Sp I-I, Sp I-2, $S p /-3, S p I-4, S p I-5$ and Sp I-6 from the upstream are indicated by underlining and shown below the sequence. SpI-A contains SpI-I and SpI-2 sites, and Sp I-B contains Sp I-4, Sp I-5 and Sp I-6 sites. TATA box is also indicated by underlining.

negative control, the intensity of the band was slightly reduced. However, the effect of pre-immune IgG was much weaker than that of anti-Sp1 or anti-Sp3 antibody. Thus, the effect of preimmune IgG was probably due to non-specific interference of the IgG protein with the binding of $\mathrm{Sp} 1$ or $\mathrm{Sp} 3$ protein and DNA.

\section{Histone acetylation in TYS cells induced by vesnarinone}

We investigated whether or not vesnarinone induced histone acetylation in TYS cells. Vesnarinone clearly induced histone acetylation in TYS cells like as TSA did (Figure 5).

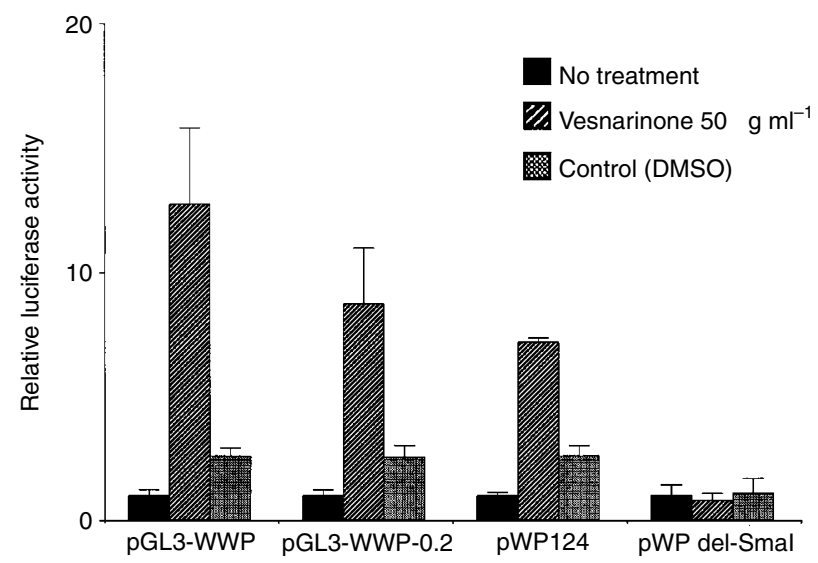

Figure 3 Luciferase assay. TYS cells were seeded in $35 \mathrm{~mm}$ dishes in DMEM supplemented with I0\% FCS. Twenty-four hours later, the cells were transfected in triplicate with $5 \mu \mathrm{g}$ of the several reporter plasmids by use of the Superfect reagent. Fifteen hours after transfection, vesnarinone $\left(50 \mu \mathrm{g} \mathrm{ml}^{-1}\right)$ was added, and $20 \mathrm{~h}$ later, cell lysates were collected. The luciferase activities of the cell lysates were measured with a Promega luciferase assay kit. Luciferase activities were normalized by the amount of protein in cell lysates. Data are shown as means (bars, s.d.), and are representative of three separate experiments with similar results.
A

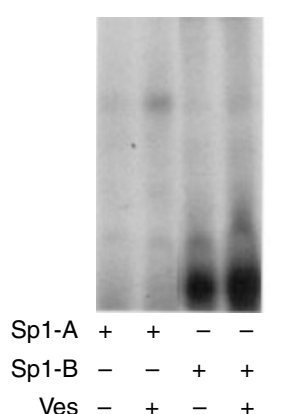

C

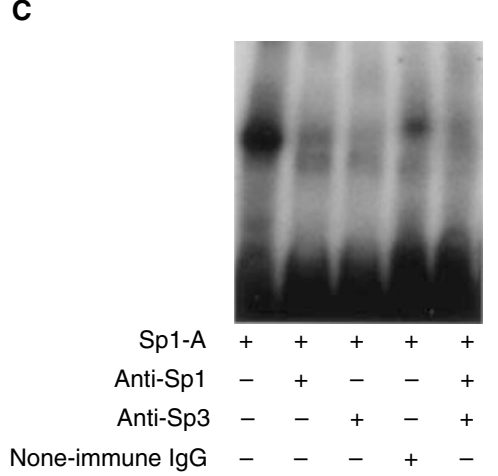

Figure 4 Electrophoretic mobility-shift assay $(\mathbf{A}, \mathbf{B})$ and supershift assay (C). Nuclear extracts prepared from vesnarinone $\left(50 \mu \mathrm{g} \mathrm{ml}^{-1}\right)$ - or DMSO-treated TYS cells were incubated with a ${ }^{32}$ P-labelled Sp I-A probe or Sp I-B probe $(\mathbf{A})$. Nuclear extracts from TYS cells after treatment with vesnarinone for 15, 30, $45 \mathrm{~min}$ and a labelled Sp I-A probe were incubated in the binding buffer $(\mathbf{B})$. Protein samples were prepared from TYS cells after treatment with vesnarinone for $45 \mathrm{~min}$. Polyclonal antibody against $\mathrm{Spl}$ and/or Sp3 was added to the binding reaction and incubated for 20 min at room temperature before addition of a labelled Sp I-A probe (C). 


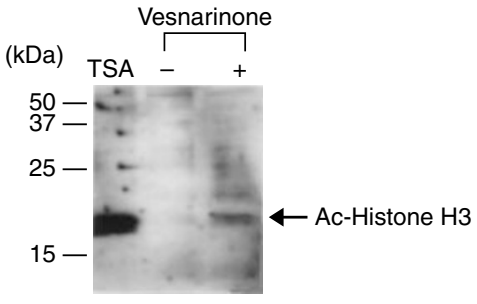

Figure 5 Histone acetylation in TYS cells induced by vesnarinone. Nuclear extracts were prepared from TYS cells after treatment with $50 \mu \mathrm{g} \mathrm{ml}^{-1}$ vesnarinone or $\left.10 \mu \mathrm{g} \mathrm{m}\right|^{-1}$ TSA for $16 \mathrm{~h}$. Protein samples were subjected to SDS-PAGE, transferred to nitrocellulose, and detected with an anti-acetylated Histone $\mathrm{H} 3$ antibody and Amersham ECL kit.

\section{DISCUSSION}

In this study, we examined the molecular mechanisms of the transcriptional regulation of $p 21^{\text {wafl }}$ gene by a differentiation inducing drug, vesnarinone. We identified the minimal vesnarinone-responsive element in the $p 21^{\text {wafl }}$ promoter at -124 to -61 relative to the transcription start site, and demonstrated that vesnarinone enhanced the binding of the transcription factors Sp1 and Sp3 to the vesnarinone-responsive element. Furthermore, we found that vesnarinone induced the histone acetylation in TYS cells.

Spl is a ubiquitously expressed nuclear protein that is initially identified as a protein that binds and stimulates transcription of simian virus 40 early promoter (Dynan and Tjian, 1983). Sp1 protein binds to the GC-rich sequences present in a variety of cellular and viral promoters and stimulates their transcriptional activity (Lania et al, 1997). Sp3 belongs to the same family of Sp1 related transcription factor, and it also binds to the GC-rich sequences (Sp1 binding sites) (Lania et al, 1997). In the $p 21^{\text {waf } 1}$ promoter, there are four independent $S p 1$ binding sites (Sp1-1$S p 1-4)$ and two overlapping $S p 1$ binding sites (Sp1-5, Sp1-6) (Figure 2). We identified the $S p 1-1$ and $S p 1-2$ site as main vesnarinone-responsive elements of the $p 21^{\text {wafl }}$ promoter. Generally, eukaryotic transcription is regulated by more than one transcription factor, and these transcription factors form a complex in specific promoter elements via interaction with various cofactors (Struhl and Moqtaderi, 1998). Sp1 and Sp3 are likely to be transcription factors that have low specificity to the extra-cellular stimuli, but they would be indispensable factors in p53-indepen-

\section{REFERENCES}

Avantaggiati ML, Ogryzko V, Gardner K, Giordano A, Levine AS, Kelly K (1997) Recruitment of p300/CBP in p53-dependent signal pathways. Cell 89: $1175-1184$

Biggs JR, Kudlow JE, Kraft AS (1996) The role of the transcription factor Sp1 in regulating the expression of the WAF1/CIP1 gene in U937 leukemic cells. J Biol Chem 271: $901-906$

Chen WY, Bailey EC, McCune SL, Dong J-Y, Townes TM (1997) Reactivation of silenced, virally transduced genes by inhibitors of histone deacetylase. Proc Natl Acad Sci USA 94: 5798-5803

Chin YE, Kitagawa M, Su W-CS, You Z-H, Iwamoto Y, Fu X-Y (1996) Cell growth arrest and induction of cyclin-dependent kinase inhibitor $\mathrm{p} 21^{\text {waf1/cip } 1}$ mediated by STAT1. Science 272: 719-722

Datto MB, Yu Y, Wang XF (1995) Functional analysis of the transforming growth factor $\beta$ responsive elements in the WAF1/Cip1/p21 promoter. $J$ Biol Chem 270: $28623-28628$

Dion LD, Goldsmith KT, Tang D-c, Engler JA, Yoshida M, Garver Jr RI (1997) Amplification of recombinant adenoviral transgene products occurs by inhibition of histone deacetylase. Virology 231: 201-209 dent pathway on the $p 21^{\text {wafl }}$ gene transcriptional activity in our system.

Vesnarinone induced histone acetylation in TYS cells. Recent studies demonstrated that there were various kinds of histone acetyltransferase (HAT) and histone deacetylase (HDAC) in mammalian cells, and the level of histone acetylation was controlled by equilibrium of the activities of HAT and HDAC (Grunstein, 1997). The transcriptional coactivators, p300 and CREB binding protein (CBP) are known to possess the HAT activity, and interact with a wide range of DNA binding proteins, including Sp1, p53, the RelA (p65) nuclear factor $\kappa \mathrm{B}$ subunit, E2F, MyoD, activator protein 1, several nuclear receptors, and many others (Yuan et al, 1996; Avantaggiati et al, 1997; Gu and Roeder, 1997; Lee et al, 1998; Ikeda et al, 2000). Although data was not shown, we confirmed the expressions of p300, CBP and HDAC1 proteins in the nucleus of TYS cells.

Several histone acetylation inducing drugs show the growthinhibitory effect or differentiation-inducing effect, and are used as a chemotherapeutic agent on several human malignancies (Chen et al, 1997; Dion et al, 1997; McCaffrey et al, 1997). The molecular targets for the differentiation inducing drugs (or histone acetylation inducing drug) may be different from those for DNAdamaging drugs. Moreover, activating pathway of the target molecules by differentiation inducing drugs may also be different from those by DNA-damaging drugs. Thus, the differentiation inducing drugs, such as vesnarinone may act synergistically on the induction of $p 21^{\text {wafl }}$ gene with the DNA-damaging therapy, such as radiation and the administration of conventional chemotherapeutic drugs. These informations are useful for creating new strategy for differentiation-inducing-therapy.

\section{ACKNOWLEDGEMENTS}

We are indebted to $\mathrm{Dr} B$ Vogelstein (The Johns Hopkins Oncology Center) for WWP-LUC and Dr Toshiyuki Sakai (Kyoto Prefectural University of Medicine) for $p W P 124$ and pWPdel-SmaI. We would like to thank Drs Mitsunobu Sato and Hideo Yoshida (Department of Oral and Maxillofacial Surgery, Tokushima University School of Dentistry) for their encouragement on this project. We would like to thank Ms Chiaki Matsuyama-Sato, Ms Ayako Shimizu, Ms Takako Ohtsuki, and Ms Midori Matsuura for their excellent technical assistance.
Dulic V, Kaufmann WK, Wilson SJ, Tlsty TD, Lees E, Harper JW, Elledge SJ, Reed SI (1994) p53-dependent inhibition of cyclin-dependent kinase activities in human fibroblasts during radiation-induced G1 arrest. Cell 76: $1013-1023$

Dynan WS, Tjian R (1983) The promoter-specific transcription factor Sp1 binds to upstream sequences in the SV40 early promoter. Cell 35: 79-87

El-Deiry WS, Tokino T, Velculescu VE, Levy DB, Parsons R, Trent JM, Lin D, Mercer WE, Kinzler KW, Vogelstein B (1993) WAF1, a potential mediator of p53 tumor suppression. Cell 75: 817-825

Grunstein M (1997) Histone acetylation in chromatin structure and transcription. Nature 389: $349-352$

Gu W, Roeder RG (1997) Activation of p53 sequence-specific DNA binding by acetylation of the p53 C-terminal domain. Cell 90: 595-606

Ikeda A, Sun X, Li Y, Zhang Y, Eckner R, Doi TS, Takahashi T, Obata Y, Yoshioka K, Yamamoto K (2000) p300/CBP-dependent and -independent transcriptional interference between NF-kB RelA and p53. Biochem Biophys Res Commun 272: 375-379 
Jiang H, Lin J, Su ZZ, Collart FR, Huberman E, Fisher PB (1994) Induction of differentiation in human promyelocytic HL-60 leukemia cells activates p21, WAF1/CIP1, expression in the absence of p53. Oncogene 9: $3397-$ 3406

Kawamata H, Nakashiro K, Uchida D, Hino S, Omotehara F, Yoshida H, Sato M (1998) Induction of TSC-22 by treatment with a new anti-cancer drug, vesnarinone, in a human salivary gland cancer cell. $\mathrm{Br}$ J Cancer 77: 71-78

Kawamata H, Hattori K, Omotehara F, Uchida D, Hino S, Sato M, Oyasu R (1999) Balance between activated-STAT and MAP kinase regulates the growth of human bladder cell lines after treatment with epidermal growth factor. Int J Oncol 15: 661-667

Lania L, Majello B, De Luca P (1997) Transcriptional regulation by the Sp family proteins. Int J Biochem Cell Biol 29: 1313-1323

Lee CW, Sorensen TS, Shikama N, La Thangue NB (1998) Functional interplay between p53 and E2F through co-activator p300. Oncogene 16: $2695-$ 2710

Liu M, Iavarone A, Freedman LP (1996) Transcriptional activation of the human p $21^{\text {waf1 }}$ gene by retinoic acid recepter. J Biol Chem 271: $31723-$ 31728

McCaffrey PG, Newsome DA, Fibach E, Yoshida M, Su MS-S (1997) Induction of $\gamma$-globin by histone deacetylase inhibitors. Blood 90: 2075-2083

Nakano K, Mizuno T, Sowa Y, Orita T, Yoshino T, Okuyama Y, Fujita T, Ohtani-Fujita N, Matsukawa Y, Tokino T, Yamagishi H, Oka T, Nomura $\mathrm{H}$, Sakai T (1997) Butyrate activates the WAF1/Cip1 gene promoter through Sp1 sites in p53-negative human colon cancer cell line. J Biol Chem 272: 22199-22206
Sato M, Kawamata H, Harada K, Nakashiro K, Ikeda Y, Gohda H, Yoshida H, Nishida T, Ono K, Kinoshita M, Adachi M (1997a) Induction of cyclindependent kinase inhibitor, $\mathrm{p} 21^{\text {waf1 }}$, by treatment with 3,4-dihydro-6-[4(3, 4-dimethoxybenzoyl)-1-piperazinyl]-2-(1H)-quinolinone (vesnarinone) in a human salivary cancer cell line with mutant p53 gene. Cancer Lett 112: $181-189$

Sato M, Harada K, Yura Y, Bando T, Azuma M, Kawamata H, Iga H, Yoshida $\mathrm{H}$ (1997b) Induction of tumour differentiation and apoptosis and $\mathrm{Le}^{\mathrm{Y}}$ antigen expression in treatment with differentiation-inducing agent, vesnarinone, of a patient with salivary adenoid cystic carcinoma. Apoptosis 2: $106-113$

Sato M, Harada K, Yura Y, Azuma M, Kawamata H, Iga H, Tsujimoto H, Yoshida H, Adachi M (1997c) The treatment with differentiation- and apoptosis-inducing agent, vesnarinone, of a patient with oral squamous cell carcinoma. Apoptosis 2: $313-318$

Struhl K, Moqtaderi Z (1998) The TAFs in the HAT. Cell 94: 1-4

Yanagawa T, Hayashi Y, Yoshida H, Yura Y, Nagamine S, Bando T, Sato M (1986) An adenoid squamous carcinoma-forming cell line established from an oral keratinizing squamous cell carcinoma expressing carcinoembryonic antigen. Am J Pathol 124: 496-509

Yuan W, Condorelli G, Caruso M, Felsani A, Giordano A (1996) Human p300 protein is a coactivator for the transcription factor MyoD. J Biol Chem 271: 9009-9013 